\title{
Effect of light source on growth performance and some physiological responses of broiler chicks
}

\author{
Abd-Elhamed E.M.Y., Z.S.H. Ismail, T.A. Marwan and A.H.H. Ali* \\ Animal and Poultry Production Department, Faculty of Agriculture, South Valley University, 83523 \\ Qena, Egypt
}

\begin{abstract}
The study aimed to investigate the effect of light source on growth performance and physiological response of broilers. A total number of one hundred and ninety-two unsexed seven-day old; Cobb broiler chicks were used in this study. Chicks were allocated into two treatment groups. Each treatment consisted of twelve replicates eight birds each. Birds in treatment 1 were exposed to yellow-reddish light produced from 60-watt incandescent lamps, while those in treatment 2 were subjected to white light by using 26 watt saving lamps. The light intensity for all experimental birds were 5 lux at the level of a bird till the end of experiment. Results showed that, using 26 watt saving lamps significantly increased body weight and body weight gain at 28, 35 and 42 days of age, feed consumption at 42 days of age and improved feed conversion ratio from 21-28 and 7-42 days of age. Moreover, using saving lamps significantly increased glucose, HDL and uric acid concentrations and significantly reduced all of creatinine, triglyceride and VLDL. It could be concluded that the using saving lamps as lighting source is more beneficial than the yellow-reddish light produced from 60 -watt incandescent lamps.
\end{abstract}

Keywords: Broilers; Blood parametres; Light source; Performance

\section{Introduction}

Light is one of the important factors for the production performance of broiler. Lighting is an essential component of successful commercial poultry production (Patel et al., 2016). Many physiological and behavioral aspects of broiler is affected by lightening. Light is essential for vision and color discrimination. The essential function of broiler such as body temperature, feeding, digestion is directly or indirectly affected by light (Utshav, 2019). Light also controls the activities of different hormones and affects growth maturation and development of organism

\footnotetext{
*Corresponding author: A.H.H. Ali

Email: attai73@yahoo.com

Received: November 10, 2020;

Accepted: December 19, 2020;

Published: December 26, 2020.
}

(Utshav, 2019). So, the broiler producer must consider several critical factors in the design of lighting program to maximize growth rate, allow maximum feeding time and conscious feed consumption (Lien et al., 2007; Kalaba et al., 2016). Light emitting diodes (LED) are becoming increasingly more popular for use in poultry barns, although more expensive initially, LED lights can last up to 50,000 hrs and are much more energy efficient compared to other kinds of lighting (Rierson, 2011). Therefore, the aim of this study is to evaluate the effect of light source on growth performance and some physiological responses of broiler chicks.

\section{Materials and Methods}

The experiment was performed at the Experimental Poultry Farm, Department of 
Animal and Poultry production, Faculty of Agriculture, University of South Valley, Egypt one hundred and ninety-two, seven days-old Cobb broiler chicks were individually weighed, and randomly assigned to two experimental groups of light sources, as follows: Birds in group 1 were exposed to yellow-reddish light produced from 60-watt incandescent lamps, while those in Group 2 were subjected to white light by using 26 watt saving lamps. The light intensity for all experimental birds were 5 lux at the level of a bird till the end of experiment. Each treatment comprised twelve replicates of 8 chicks each. Chicks were housed and raised in two tiers-wire floor, batteries with cages having the dimensions (width: $97 \mathrm{~cm}$; length: $50 \mathrm{~cm}$; height: $45 \mathrm{~cm}$ ), located in a closed broiler house under controlled managerial and hygienic conditions. The interior temperature which started by about $32^{\circ} \mathrm{C}$ at seventh day of age, was reduced by about $2{ }^{\circ} \mathrm{C}$ every week to reach $24{ }^{\circ} \mathrm{C}$ at the fourth week of age and remained constant in the presence of a relative humidity ranging between $55-60 \%$ up to the end of the experiment. The birds were fed on starter and grower diets from 7 to 21 and 22 to 42 days of age, respectively (Table, 1) and the feed and water were available all the time.

Studied criteria: Birds per each replicate were weekly weighed on individual basis, then the body weight gain (BWG) was calculated as the difference between final and the initial body weight. The average feed consumption (FC) per each replicate were weekly calculated as the difference between the offered and remained amounts of feed. The mean feed conversion ratio (FCR) were weekly calculated by dividing total feed consumed by the total BWG of birds per each replicate. Number of dead birds were daily recorded and the mortality rate was calculated for each replicate and treatment. At the end of the experiment at 42 days of age, 24 birds, per each group i.e. two around the average weight / each replicate were slaughtered. After complete bleeding, they were scalded and mechanically plucked. Blood samples well be collected from the chicks into collecting tube and allowed to clot at $5^{\circ} \mathrm{C}$ overnight, and then centrifuged at $3000 \mathrm{rpm}$ for 15 minutes. Blood serum well be obtained and stored at $-20^{\circ} \mathrm{C}$ until analysis. Moreover, $3 \mathrm{ml}$ of fresh blood sample well be collected into heparinized collecting tube. Two drops of blood from each sample were smeared on two glass slides. The smears were stained within 2 to $3 \mathrm{hrs}$ using Leishman Stain. One hundred leukocytes, including lymphocytes (L), heterophils $(\mathrm{H})$, monocytes, basophils and eosinophils were counted on each slide as described by (Sturkie, 1986). Slides were counted for each chick. The packed cell volume (PCV), hemoglobin concentration (HB), Creatinine and Uric acid were determined using the commercial diagnostic kits produced by the manufacturer companies (Spectrum, Diagnostics, Egypt. Co. for Biotechnology, SAE).

\section{Blood serum constituents:}

Obtained blood sera were collected to determine: cholesterol (Wiebe and Bernert, 1984); glucose (Trinder, 1969); triglyceride (Schmit, 1964); very low density lipoprotein (VLDL) (Friedewald et al., 1972), high-density lipoprotein (HDL) was determined according to (Warnick, 1983) and low-density lipoprotein (LDL) (Assmann et al., 1984).

Data collected were statistically analyzed by the analysis of variance with the General Linear Model (GLM) procedure of the SAS Institute (SAS, 1996). All statements of significance are based on the 0.05 level of probability. Significant differences among treatments were performed using Duncan's multiple range test (Duncan, 1955). 
Table 1. Composition and calculated analysis of the starter and grower basal diets.

\begin{tabular}{|l|c|c|}
\hline \multicolumn{1}{|c|}{ Ingredients (\%) } & Starter & Grower \\
\hline Yellow corn & 52.59 & 56.04 \\
Soybean meal (44\% CP) & 32.00 & 30.00 \\
Corn gluten (60\% CP) & 9.00 & 6.00 \\
Vegetable oil & 2.00 & 4.00 \\
Premix* & 0.30 & 0.30 \\
Dicalcium phosphate & 2.00 & 1.80 \\
Limestone & 1.00 & 1.00 \\
Lysine & 0.30 & 0.20 \\
Methionine & 0.25 & 0.125 \\
Choline chloride & 0.20 & 0.175 \\
Salt & 0.36 & 0.36 \\
Total & 100 & 100 \\
\hline Calculated values ${ }^{* *}$ & \multicolumn{2}{|c|}{} \\
\hline Crude protein \% & 23.33 & 20.42 \\
ME (Kcal/kg) & 3115 & 3162 \\
Calcium \% & 0.91 & 0.86 \\
Av. Phosphorus \% & 0.48 & 0.43 \\
Methionine & 0.74 & 0.55 \\
Lysine \% & 1.45 & 1.27 \\
\hline
\end{tabular}

* Each 1 kg contains Vit. A 12000 IU, Vit. D 2500 IU, Vit. E 10 mg, Vit. K 3 mg, Vit. B1 1 mg, Vit. B2 4 mg,

Pantothenic acid 10 mg, Folic acid 1 mg, Niacin 40 mg, Vit. B6 3 mg, Vit. B12 20 mg, Mn 62 mg, Fe 44 mg, Zn 56 mg,

$\mathrm{Cu} 5 \mathrm{mg}$ and $\mathrm{Se} 100 \mu \mathrm{g}$.

${ }^{* * *}$ Calculated according to the NRC (1994).

\section{Results and Discussion:}

\section{Productive Performance:}

\section{Body weight:}

Data of body weight (BW) at 7, 14, 21, 28, 35 and 42 days of age are presented in Table (2). Data showed that, BW was significantly $(\mathrm{P}<0.05)$ higher at 28, 35 and 42 days of age in the exposed group with white light saving lamps than the exposed group with yellowreddish light. On the other hand, the differences in BW at 7, 14 and 21 days of age were not significant between the two groups. The increase in $\mathrm{BW}$ could be attributed to the increase of FC and the improvement on FCR so the BWG raised as well as body weight. These results are in harmony with (El-Hammady et al., 2014; Rozenboim et al., 2004). In contrast, (Rodenburg and Middelkoop, 2003; Kristensen et al., 2006), reported that birds exposed to light produced from different sources did not exhibit statistical differences in BWG. 
Table 2. Averages \pm (SE) of body weight ( $\mathrm{g}$ ) of broiler chicks as affected by the light source.

\begin{tabular}{|c|c|c|c|}
\hline \multirow{2}{*}{ Days of Age } & \multicolumn{2}{|c|}{ Groups } & \multirow{2}{*}{ P value } \\
\cline { 2 - 3 } & Yellow-reddish & Saving lamps & 0.5415 \\
\hline 7 & $211.02 \pm 2.82$ & $213.02 \pm 1.57$ & 0.2562 \\
\hline 14 & $471.46 \pm 6.48$ & $480.16 \pm 7.43$ & 0.5861 \\
\hline 21 & $865.36 \pm 19.55^{2}$ & $874.11 \pm 21.15$ & 0.0274 \\
\hline 28 & $1419.34 \pm 33.66^{\mathrm{b}}$ & $1487.16 \pm 36.40^{\mathrm{a}}$ & 0.0361 \\
\hline 35 & $1977.13 \pm 44.84^{\mathrm{b}}$ & $2083.31 \pm 46.37^{\mathrm{a}}$ & 0.0030 \\
\hline 42 & $2497.69 \pm 50.55^{\mathrm{b}}$ & $2691.74 \pm 63.61^{\mathrm{a}}$ & \\
\hline
\end{tabular}

${ }^{a, b}$ Means in the same row followed by different letters are significantly different at $(\mathrm{P} \leq 0.05)$.

\subsection{Body weight gain:}

Data of daily body weight gain (DBWG) at 7-14, 14-21, 21-28, 28-35, 35-42 and 7-42 days of age are presented in Table (3). Data showed that, DBWG was significantly $(\mathrm{P}<0.05)$ higher at 21-28, 35-42 and 7-42 days of age in the exposed group with white light saving lamps than the exposed group with yellow-reddish light. While, the differences in DBWG at the rest of the periods were not significant between the two groups.

\subsection{Feed consumption:}

Data of daily feed consumption (DFC) at $14,21,28,35$ and 42 days of age are presented in Table (4). Data showed that, at all investigated periods DFC was not significant between all groups except at 42 days of age where the exposed group with white light saving lamps was significantly $(\mathrm{P}<0.05)$ higher than the other group. The increase of DFC at 42 days may be due to the increase in $\mathrm{BW}$ at this age in white saving lamps group as a result of improvement in FCR in this group than the yellow-reddish light group. These results are in harmony with (El-Hammady et al., 2014; Rozenboim et al., 2004).

\subsection{Feed conversion ratio:}

Data of FCR at 7-14, 14-21, 21-28, 28-35, $35-42$ and 7-42 days of age are presented in Table (5). Data showed that, feed convertion ratio (FCR) was significantly $(\mathrm{P}<0.05)$ improved at 21-28, 35-42 and 7-42 days of age in the exposed group with white light saving lamps than the exposed group with yellowreddish light. While, the differences in FCR at the all another periods were not significant between the two groups. The improvement of FCR may be due to white light saving lamps enabled chicks to enhance metabolism and digestion of nutrients more efficiently than the yellow-reddish light. These results are in harmony with (El-Hammady et al., 2014; Rozenboim et al., 2004). 
Table 3. Averages \pm (SE) of DBWG (gm) of broiler chicks as affected by the light source.

\begin{tabular}{|c|c|c|c|}
\hline \multirow{2}{*}{ Days of Age } & Yellow-reddish & Saving lamps & \multirow{2}{*}{ P value } \\
\cline { 2 - 3 } & $37.21 \pm 0.88$ & $38.16 \pm 1.00$ & 0.3683 \\
\hline $7-14$ & $56.27 \pm 2.24$ & $54.60 \pm 2.20$ & 0.4837 \\
\hline $14-21$ & $77.69 \pm 2.60^{\mathrm{b}}$ & $87.58 \pm 2.79^{\mathrm{a}}$ & 0.0077 \\
\hline $21-28$ & $79.68 \pm 2.99$ & 85.162 .01 & 0.2503 \\
\hline $28-35$ & $74.37 \pm 1.58^{\mathrm{b}}$ & $86.92 \pm 2.83^{\mathrm{a}}$ & 0.0002 \\
\hline $35-42$ & $65.04 \pm 1.51^{\mathrm{b}}$ & $70.49 \pm 1.80^{\mathrm{a}}$ & 0.0098 \\
\hline $7-42$ & &
\end{tabular}

${ }^{a}$ b Means in the same row followed by different letters are significantly different at $(\mathrm{P} \leq 0.05)$.

Table 4. Averages $\pm(\mathrm{SE})$ of daily feed consumption ( $\mathrm{g}$ ) of broiler chicks as affected by the light source.

\begin{tabular}{|c|c|c|c|}
\hline \multirow{2}{*}{ Days of Age } & \multicolumn{2}{|c|}{ Groups } & \multirow{2}{*}{ P value } \\
\cline { 2 - 3 } & Yellow-reddish & Saving lamps & \\
\hline 14 & $46.14 \pm 0.82$ & $47.40 \pm 0.92$ & 0.1697 \\
\hline 21 & $78.65 \pm 2.39$ & $80.94 \pm 1.89$ & 0.2885 \\
\hline 28 & $118.15 \pm 2.89$ & $120.60 \pm 3.15$ & 0.3621 \\
\hline 35 & $132.78 \pm 3.14$ & $133.50 \pm 3.32$ & 0.8804 \\
\hline 42 & $127.43 \pm 3.37^{\mathrm{b}}$ & $137.18 \pm 2.08^{\mathrm{a}}$ & 0.0197 \\
\hline $7-42$ & $100.63 \pm 2.06$ & $103.92 \pm 1.49$ & 0.1095 \\
\hline
\end{tabular}

${ }^{a}$ b Means in the same row followed by different letters are significantly different at $(\mathrm{P} \leq 0.05)$.

Table 5. Averages $\pm(\mathrm{SE})$ of daily feed consumption $(\mathrm{g})$ of broiler chicks as affected by the light source.

\begin{tabular}{|c|c|c|c|}
\hline \multirow{2}{*}{ Days of Age } & Yellow-reddish & Saving lamps & \multirow{2}{*}{ P value } \\
\cline { 2 - 3 } & $1.24 \pm 0.02$ & $1.25 \pm 0.02$ & 0.8888 \\
\hline $7-14$ & $1.41 \pm 0.03$ & $1.50 \pm 0.05$ & 0.1305 \\
\hline $14-21$ & $1.53 \pm 0.04^{\mathrm{a}}$ & $1.38 \pm 0.03^{\mathrm{b}}$ & 0.0102 \\
\hline $21-28$ & $1.68 \pm 0.04$ & $1.58 \pm 0.05$ & 0.4136 \\
\hline $28-35$ & $1.72 \pm 0.05^{\mathrm{a}}$ & $1.59 \pm 0.04^{\mathrm{b}}$ & 0.0484 \\
\hline $35-42$ & $1.55 \pm 0.02^{\mathrm{a}}$ & $1.48 \pm 0.02^{\mathrm{b}}$ & 0.0560 \\
\hline $7-42$ & &
\end{tabular}

a, b Means in the same row followed by different letters are significantly different at $(\mathrm{P} \leq 0.05)$. 


\section{Physiological responses:}

2.1. Serum glucose, creatinine, uric acid, hemoglobin concentration and packed cell volume:

Data of serum glucose, creatinine, uric acid (, hemoglobin concentration (HB)and Packed cell volume (PCV) are presented in Table (6). Data revealed that, white light saving lamps increased significantly $(\mathrm{P}<0.05)$ serum glucose and uric concentration than in the yellow-reddish light group. On the other hand, white light saving lamps group was significantly $(\mathrm{P}<0.05)$ lower in serum creatinine than the yellow-reddish light group. Nevertheless, HB concentration and PCV did not affected by light source. The increase in glucose and uric acid concentration in white light saving lamps group may be due to the increase in $\mathrm{BW}$ and what follows by increase in FC and digestion causing in rise in the levels of glucose and uric acid. But the increase in creatinine in the yellow-reddish light group may attributed to that this catabolite is directly related to increased muscle activity and in this group birds are lower in BW than the other group so birds movement is expected to be more than the heavier group. These results are in agreement with (Marcos et al., 2012).

Table 6. Averages $\pm(\mathrm{SE})$ of serum glucose, creatinine, uric acid, hemoglobin concentration (HB) and packed cell volume (PCV) of broiler chicks as affected by the light source.

\begin{tabular}{|l|c|c|c|}
\hline \multirow{2}{*}{ Triats } & \multicolumn{2}{|c|}{ Treat } & \multirow{2}{*}{ P value } \\
\cline { 2 - 3 } & Yellow-reddish & Saving lamps & 0.2211 \\
\hline PCV,$\%$ & $30.25 \pm 1.18$ & $27.75 \pm 1.62$ & 0.0010 \\
\hline Glucose, $\mathrm{mg} / \mathrm{dl}$ & $164.74 \pm 7.46^{\mathrm{b}}$ & $195.98 \pm 4.62^{\mathrm{a}}$ & 0.7479 \\
\hline HB, $\mathrm{g} / \mathrm{dl}$ & $30.62 \pm 0.42$ & $30.85 \pm 0.57$ & 0.0001 \\
\hline Creatinine, $\mathrm{mg} / \mathrm{dl}$ & $0.66 \pm 0.04^{\mathrm{a}}$ & $0.45 \pm 0.01^{\mathrm{b}}$ & 0.0001 \\
\hline Uric acid, $\mathrm{mg} / \mathrm{dl}$ & $4.25 \pm 0.15^{\mathrm{b}}$ & $5.15 \pm 0.01^{\mathrm{a}}$ & \\
\hline
\end{tabular}

a, b Means in the same row followed by different letters are significantly different at $(\mathrm{P} \leq 0.05)$.

\subsection{Serum cholesterol, triglyceride, high density lipoprotein, low density lipoprotein and very low density lipoprotein:}

Data of Serum Cholesterol (CHOL), triglyceride (TRIG), high density lipoprotein (HDL), low density lipoprotein (LDL), very low density lipoprotein (VLDL) are presented in Table (7). Data showed that, white light saving lamps decreased significantly $(\mathrm{P}<0.05)$ TRIG and VLDL than in the yellow-reddish light group. And vice versa, white light saving lamps increased significantly $(\mathrm{P}<0.05) \mathrm{HDL}$ than the yellow-reddish light group. On the other hand, CHOL and LDL were insignificantly lower in the white light saving lamps group than in the yellow-reddish light group. It is obvious that, the white light saving lamps reduced the harmful lipids in serum such as VLDL and TRIG and increased beneficial lipids HDL. These results are in disagreement with Hassan et al. (2017) who stated that, blood values of ducks were not influenced by the light treatments (yellow, green, blue and control white (fluorescent lamps)) but serum cholesterol level decreased under the blue light treatment $(\mathrm{P}<0.015)$ compared to green light treatment. 
2.3. Percentages of white blood cells differentiation:

Percentages of white blood cells: monocytes, heterophils, lymphocytes, basophilesand eosinophils are presented in Table (8). Data explained that the differences between all treated groups were not significant.
These results are in agreement with Kim et al. (2013) who stated that, white blood cell counts and hemoglobin percent did not affect by light treatments (incandescent bulbs (as a control) and light-emitting diode white light, blue light, red light, green light, and yellow light).

Table 7. Averages \pm (SE) of serum cholesterol, triglyceride, high density lipoprotein (HDL), low density lipoprotein (LDL) and very low density lipoprotein (VLDL) of broiler chicks as affected by the light source.

\begin{tabular}{|l|c|c|c|}
\hline \multirow{2}{*}{ Traits } & \multicolumn{2}{|c|}{ Groups } & \multirow{2}{*}{ P value } \\
\cline { 2 - 4 } & Yellow-reddish & Saving lamps & \\
\hline Cholesterol, mg/dl & $156.78 \pm 3.42$ & $149.60 \pm 1.98$ & 0.0755 \\
\hline Triglyceride, mg/dl & $96.34 \pm 3.34^{\mathrm{a}}$ & $67.28 \pm 1.74^{\mathrm{b}}$ & 0.0001 \\
\hline HDL, mg/dl & $98.73 \pm 2.01^{\mathrm{b}}$ & $106.16 \pm 1.93^{\mathrm{a}}$ & 0.0106 \\
\hline LDL, mg/dl & $38.78 \pm 4.04$ & $29.99 \pm 2.83$ & 0.0555 \\
\hline VLDL, mg/dl & $19.27 \pm 0.67^{\mathrm{a}}$ & $13.46 \pm 0.35^{\mathrm{b}}$ & 0.0001 \\
\hline
\end{tabular}

${ }^{\mathrm{a}, \mathrm{b}}$ Means in the same row followed by different letters are significantly different at $(\mathrm{P} \leq 0.05)$.

Table 8. Averages \pm (SE) of percentage white blood cells differentiation as affected by the light source for broilers.

\begin{tabular}{|c|c|c|c|}
\hline \multirow{2}{*}{ WBCs, \% } & \multicolumn{2}{|c|}{ Groups } & \multirow{2}{*}{ P value } \\
\cline { 2 - 4 } & Yellow-reddish & Saving lamps & 0.8288 \\
\hline Lymphocytes & $58.96 \pm 1.25$ & $59.71 \pm 1.15$ & 0.2874 \\
\hline Heterophiles & $35.25 \pm 1.18$ & $33.91 \pm 1.02$ & 0.2521 \\
\hline Monocytes & $1.79 \pm 0.16$ & $2.04 \pm 0.15$ & 0.2917 \\
\hline Basophiles & $2.62 \pm 0.19$ & $2.96 \pm 0.24$ & 1.0000 \\
\hline Eosinophils & $1.38 \pm 0.10$ & $1.38 \pm 0.10$ & \\
\hline
\end{tabular}

\section{CONCLUSION}

Considering the results of the current study it could be concluded that, exposed broiler chicks with white light saving lamps has the potential to improve productive performance (body weight, body weight gain and feed conversion) and some physiological traits as compared with chicks exposed to yellow-reddish light, so it is best to use white light saving lamps as a source of light in the broiler production.

\section{References}


Assmann, G, Jabs H.V., Kohnert U., Nolte W. and Schriewer H. (1984)'LDL-cholesterol polyvinyl sulphate method (kit of LDL)' Clin. Chem. Acta., 140, pp.77-83.

Duncan, D. B. (1955). Multiple ranges and multiple F-test. Biometric, 11, pp. 1042.

El-Hammady H.Y., El-Sagheer M., Hassanien H.H.M. and Hassan H.A. (2014) 'Impact of light source and feed form on growth performance and carcass traits of broiler chicks' The $7^{\text {th }}$ International Poultry Conference, Ain-Sukhna- Red Sea, Egypt, pp.3-6.

Friedewald W.T., Levy R.F. and Fredrickson D.S. (1972) 'Estimations of the concentration of low density lipoprotein cholesterol in plasma, without use of the preparative ultracentrifuge' Clinical Chemistry, 18, pp. 499-502.

Hassan M.R., Sultana S. and Ryu K.S. (2017) 'Effect of various monochromatic LED light colors on performance, blood properties, bone mineral density, and meat fatty acid composition of ducks' J. Poult. Sci., 54(1), pp. 66-72.

Kalaba, Z. M. A.; El. Sherif, Kh. and AbdElrahman, A. M. (2016) 'Effect of lighting program on productive and physiological performance of broiler chicks' J.Animal and Poultry Prod., Mansoura Univ., 7(8), pp. 313- 317.

Kim M.J. , Parvin R., Mushtaq M.M.H. , Hwangbo J. , Kim J. H. , Na J.C. , Kim D.W. , Kang H.K. , Kim C.D. , Cho K.O. , Yang C.B. and Choi H.C. (2013) 'Growth performance and hematological traits of broiler chickens reared under assorted monochromatic light sources' Poult. Sci. 92(6), pp. 1461-1466.
Kristensen, H.H., Perry,G.C., Prescott,N.B., Ladewig, J., Ersbøll, A.K. and Wathes, C.M. (2006) 'Leg health and performance of broiler chickens reared in different light environments' British Poult. Sci., 47, pp. 257-263.

Lien, R.J., Hess, J.B., Mckee, S.R., Bilgili, S.F. and Townsend, T.C (2007) 'Effect of light intensity and photoperiod on live performance, heterophil-to- lymphocyte ratio, and processing yields of broilers' Poult.Sci., 86, pp. 1287-1293.

Marcos, B.C., Fabrício, P.R., Hugo, R.M., Mara, R.B. de Mattos, N., Antônio, V.M., and Cristiane, F.P.M. (2012) 'Biochemical Blood Parameters of Broilers at Different Ages under Thermoneutral Environment' World's Poultry Science Journal, Poster Presentation Salvador - Bahia - Brazil, pp. 143-146

NRC, National Research Council, 1994. Nutrient Requirements of Poultry. 9th Review Edition, National Academy Press, Washington, D.C.

http://www.lamolina.edu.pe/zootecnia/biblioteca2012/NRC\% 20Poultry\%201994[1].pdf.

Patel S. J., Patel, A. S., Patel, M. D. and Patel, J. H. (2016) 'Significance of light in poultry production: A Review' Advances in Life Sciences 5(4), pp. 1154-1160.

Rierson, R. D. (2011) 'Broiler preference for light color and feed form, and the effect of light on growth and performance of broiler chicks' Master of Science, College of Agriculture, Kansas State University, Manhattan, Kansas, USA.

Rodenburg, J.V.H. and Middelkoop, J.H.V. (2003) 'Effect of coloured light on production and welfare traits in broilers' T. Applied Research, Animal Sciences 
Group, Wageningen UR, P.O. Box 2176, 8203 AD Lelystad, The Netherlands.

Rozenboim I., Biran, I., Chaiseha, Y., Yahav, S., Rosenstrauch, A., Sklan, D. and Halevy, O. (2004) 'The effect of a green and blue monochromatic light combination on broiler growth and development' Poultry Science, 83 pp. 842-845.

SAS, (1996). SAS User's Guide, statistics (6.2th Ed.) Cary NC: SAS Institute Inc.

Schmit, J. M. (1964) 'Colorimetric determination of total lipid' $\mathrm{PhD}$. Thesis', Lyon: Lyon University, France.

Sturkie, P.D (1986) ‘Avian physiology’ by P.D. Sturkie, 4th ed., Springer-Verlag, New York. INC.
Trinder, P. (1969) 'Test-compination, enzymatic determination of glucose' Ann. Clin. Biochem, 6, pp. 24.

Utshav, P. (2019) 'Effect of lighting in broiler production: A Review' Acta Scientific Agriculture 3(6), pp. 114-116.

Warnick, (1983) 'HDL - cholesterol procedure No OSSgg (kit of HDL - cholesterol) selection methods' Clin. Chem., 10, pp. 91 -99 .

Wiebe, D. A. and Bernert, J. T., (1984) 'Influence of incomplete cholesteryl ester hydrolysis on enzymic measurements of cholesterol 'Clin. Chem. 30(3), pp. 352356. 